\title{
Summer and autumn movements of white whales Delphinapterus leucas in Svalbard, Norway
}

\author{
Christian Lydersen ${ }^{1, *}$, Anthony R. Martin ${ }^{2}$, Kit M. Kovacs ${ }^{1,3}$, Ian Gjertz ${ }^{1}$ \\ ${ }^{1}$ Norwegian Polar Institute, N-9296 Tromsø, Norway \\ ${ }^{2}$ National Environmental Research Council, Sea Mammal Research Unit, University of St Andrews, \\ St Andrews KY16 8LB, Scotland, United Kingdom \\ ${ }^{3}$ The University Courses on Svalbard (UNIS), 9170 Longyearbyen, Norway
}

\begin{abstract}
Fifteen adult white whales Delphinapterus leucas were fitted with satellite relay data loggers (SRDLs) in order to study their distribution and movement patterns in Svalbard. A total of $844 \mathrm{~d}$ of tracking data was recorded. The average longevity of the SRDLs was $56 \pm 30$ (SD) d (range 7 to $120 \mathrm{~d}$ ). The tracking data were analysed using a computer visualisation system, which allowed the movement patterns to be animated against a background map of the study area. This enabled classification of the whales' tracking data into 4 major activity patterns: (1) glacier front stationary ( $55.6 \%$ of the time), (2) in-fjord movements ( $10.6 \%$ of the time), (3) coastal movements $(26.0 \%$ of the time), and (4) coastal stationary ( $7.8 \%$ of the time). The whales spent most of their time relatively stationary, close to different glacier fronts in the area. These areas are known to have a high abundance of potential prey species for white whales, so foraging is the probable reason for this behaviour. When the whales changed location, they did so in an apparently directed and rapid manner. Average horizontal swimming speed was at least $6 \mathrm{~km} \mathrm{~h}^{-1}$ during long-distance movements. Movements between glacier fronts were extremely coastal in nature and took place in shallow waters. This behaviour has probably developed as a means of avoiding predators.
\end{abstract}

KEY WORDS: White whales $\cdot$ Satellite tracking $\cdot$ Activity budget $\cdot$ Svalbard

\section{INTRODUCTION}

White whales Delphinapterus leucas are the most commonly observed and most numerous cetacean in the Svalbard Archipelago. The species has been hunted in this area since early in the 17th century, initially by Russian whalers, and also by Norwegians from 1866 (Lønø \& Øynes 1961). Knowledge of these early catches is scarce, but from 1866 until whaling ended at the start of the 1960s, about 15000 whales were caught (Lønø \& Øynes 1961, Gjertz \& Wiig 1994). Despite the relative abundance of these whales in Svalbard, and the fact that they have been exposed to hunting for centuries, very little is known about their biology in Norwegian waters.

*E-mail: Lydersen@npolar.no
Knowledge of distribution and movement patterns is essential for management of a species. Since the early 1990s such information has been collected from white whales from various parts of the Arctic via the use of satellite telemetry (Martin et al. 1993, Smith \& Martin 1994, Richard et al. 1997, 1998, 2001). In the Canadian high Arctic, white whales were found to spend a lot of their time in shallow estuaries during summer (Martin et al. 1993, Smith \& Martin 1994). The relatively warm freshwater in these areas is thought to be advantageous for the whales' annual moulting process (St Aubin et al. 1990, Smith et al. 1992). The whales in these areas generally move in and out of estuaries to exploit benthic feeding opportunities in deeper waters offshore (Smith \& Martin 1994). White whales in the Beaufort Sea spend little time in estuaries during summer (Richard et al. 1997). Males in particular spent most of their time far offshore, deep into the Arctic 
Ocean, and move thousands of kilometres from Canadian waters into Alaskan and eventually into Russian waters. In some study areas the tagged white whales tend to follow the seasonal patterns of ice distribution, remaining near the expanding or retracting ice edges (Martin et al. 1993, Richard et al. 1998). However, the whales tagged in the Beaufort Sea were found to move rapidly through heavy pack-ice (more than 9/10 cover: Richard et al. 1997), which contradicts the general perception that these animals are restricted only to open water or loose pack-ice areas.

The picture that emerges from the satellite tracking studies of white whales described above is that, for whatever reason, they demonstrate highly variable movement patterns in different geographical areas. The purpose of the present study was to study the summer and autumn movements of white whales in Svalbard, Norway.

\section{MATERIALS AND METHODS}

This study was conducted in several fjords of Spitsbergen, the largest island within the Svalbard Archipelago, Norway, during the summers of 1995 to 1999. During the first $3 \mathrm{yr}$, fieldwork was conducted on the west coast of Spitsbergen in the van Mijenfjorden and van Keulenfjorden area (Fig. 1). Fieldwork in 1998 and 1999 was conducted in the inner parts of Storfjorden on the east side of Spitsbergen (Fig. 1).

Delphinapterus leucas were captured using either a nylon net $(70 \times 30 \mathrm{~m}$, mesh size $20 \mathrm{~cm})$ or a 'trawl' net $(150 \times 8 \mathrm{~m}$, mesh size $15 \mathrm{~cm})$ set from the beach at an angle of about $45^{\circ}$. The whales were herded into the net-opening using 2 Zodiacs to direct their path. Following capture, the whales were untangled from the net and restrained in shallow water with a hoop net held around the head and a cushioned rope tied around the caudal penduncle that was anchored to shore. Standard length was measured to the nearest $5 \mathrm{~cm}$, and sex was determined based on examination of the genitalia. The whales were classified into age groups based on body size and skin colour (Brodie 1971). Only individuals classified as adults were equipped with satellite tags.

The satellite relay data loggers (SRDLs) used in this study were developed by the Sea Mammal Research Unit, University of St. Andrews, Scotland, UK. Detailed descriptions of these tags can be found in McConnell et al. (1992). Some of the SRDLs used early in this study were housed in a double-tube. Later tag designs consisted of single-tube housings. All were pressure-resistant to $1500 \mathrm{~m}$ water depth. Additionally, all tags had 2 flexible straps made of PVC-impregnated belt material cast into their undersides. The satellite tags were attached by placing the flexible belt material transversely on each side of the whale's dorsal ridge. Each strap was held in place by 2 nylon pins $(6 \mathrm{~mm}$ diameter) inserted into a hole in the strap, then through the dorsal ridge and out through a hole in the strap on the other side of the ridge. The pins were held in place using nylon nuts and washers. The handling time for each whale was less than $1 \mathrm{~h}$.

Previous studies involving satellite telemetry on white whales (Martin et al. 1993, Richard et al. 1997, 1998) show that the tags normally fall off within 3 mo. The battery capacity in our tags allowed us to sample data continuously without any duty cycling over this period. The tags would thus transmit data every time the whale surfaced and exposed the antennae after the saltwater-switch was enabled. In addition to data on geographical positions, dive data was transmitted. The details of the diving activity will be reported elsewhere.

The SRDLs transmitted to 2 or 3 polar-orbiting satellites that pick up signals within their field of view. Details on the ARGOS satellite-based data-reception system can be found in ARGOS (1989). If the quality and number of signals received in a pass satisfy certain criteria, ARGOS calculates the geographical position of the transmitting SRDL. This calculated position is assigned a quality index (Location Quality, LQ) that varies from -2 to 3 , where LQ 3 is the highest accuracy. Irregular uplink rates and variable LQs from a SLDR can potentially result in large errors in location fixes. Thus, the location data were filtered by the algorithm described by McConnell et al. (1992), using a maximum speed parameter of $2 \mathrm{~m} \mathrm{~s}^{-1}$ to remove positions that would have involved impossibly fast swimming from a reliable position (with high LQ). The filtered positions were then entered into the MAMVIS computer visualisation system (Fedak et al. 1996), which allowed the movement patterns to be animated against a background map of the study area. Based on manual playback of tracks, both forward, backward and with variable time-steps, we were able to classify the whale movements into 4 major activities: glacier front stationary, in-fjord movements, coastal movements, and coastal stationary (Fig. 2). In addition to data on positions and depth, the SRDLs also transmitted diagnostic data on the tags themselves. These data can be visualised in a stripchart and analysed in time-steps simultaneously with the tracks. Two of the tag parameters were included in our analyses to facilitate the classification of the activity categories mentioned above: these were spotdepths and the number of completed/aborted transmissions (Fig. 2: inserts). Spot-depths are simple depth profiles sampled at regular intervals. Transmissions are aborted if the SRDL detects submergence of the 

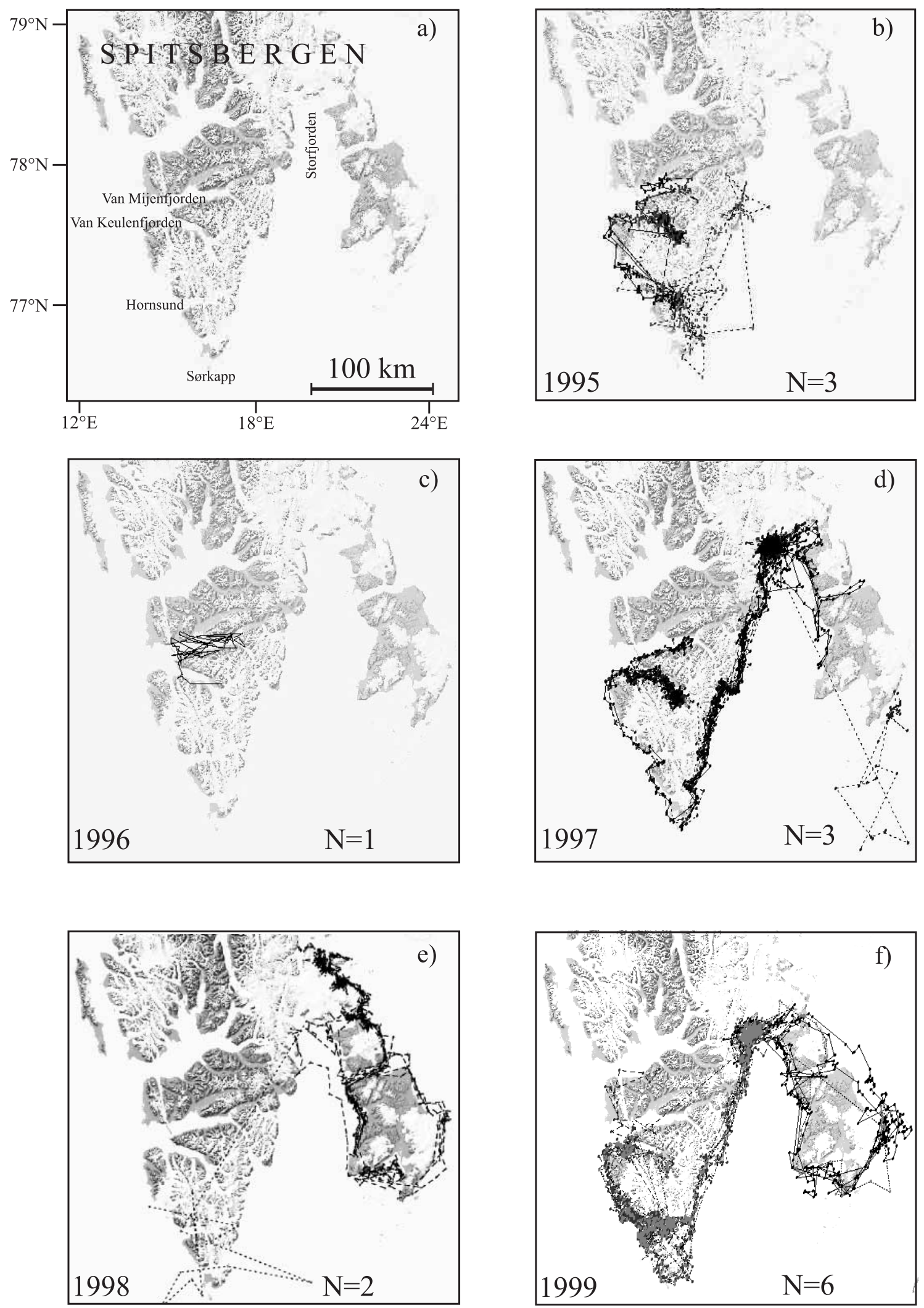

Fig. 1. Map of Svalbard (a) showing place-names mentioned in text, and (b-f) crude plots of movement patterns of Delphinapterus leucas equipped with satellite-relay data loggers during summer and autumn of 1995 to 1999 
antennae before the transmission is completed, so a higher ratio of aborted transmissions indicates short surface times, which problably occur most frequently when the whales are swimming relatively fast. Glacier front stationary activity is characterised by tracks showing whales that are basically stationary in front of a glacier (Fig. 2a). The corresponding spot-depths (Fig. 2a: inset) indicated relatively deep diving and a low frequency of aborted transmissions, suggesting that the whales were relatively stationary or at least moving slowly when at the surface. During coastal movements, whales move in what appears to be a very directed manner along the coast (Fig. 2a). The spot-depths are shallow, and the ratio of aborted transmissions is high, indicative of short surface periods. In-fjord movements are charactereised by the whales moving within a fjord without stopping for significant periods of time at any particular location (Fig. $2 b)$. Both spot-depths and the transmission performance are highly variable during this activity. Coastal stationary occurs when whales stop for a significant period of time along the coast (Fig. 2c). Spot-depths and transmission parameters during this activity are similar to the glacier front stationary activity.
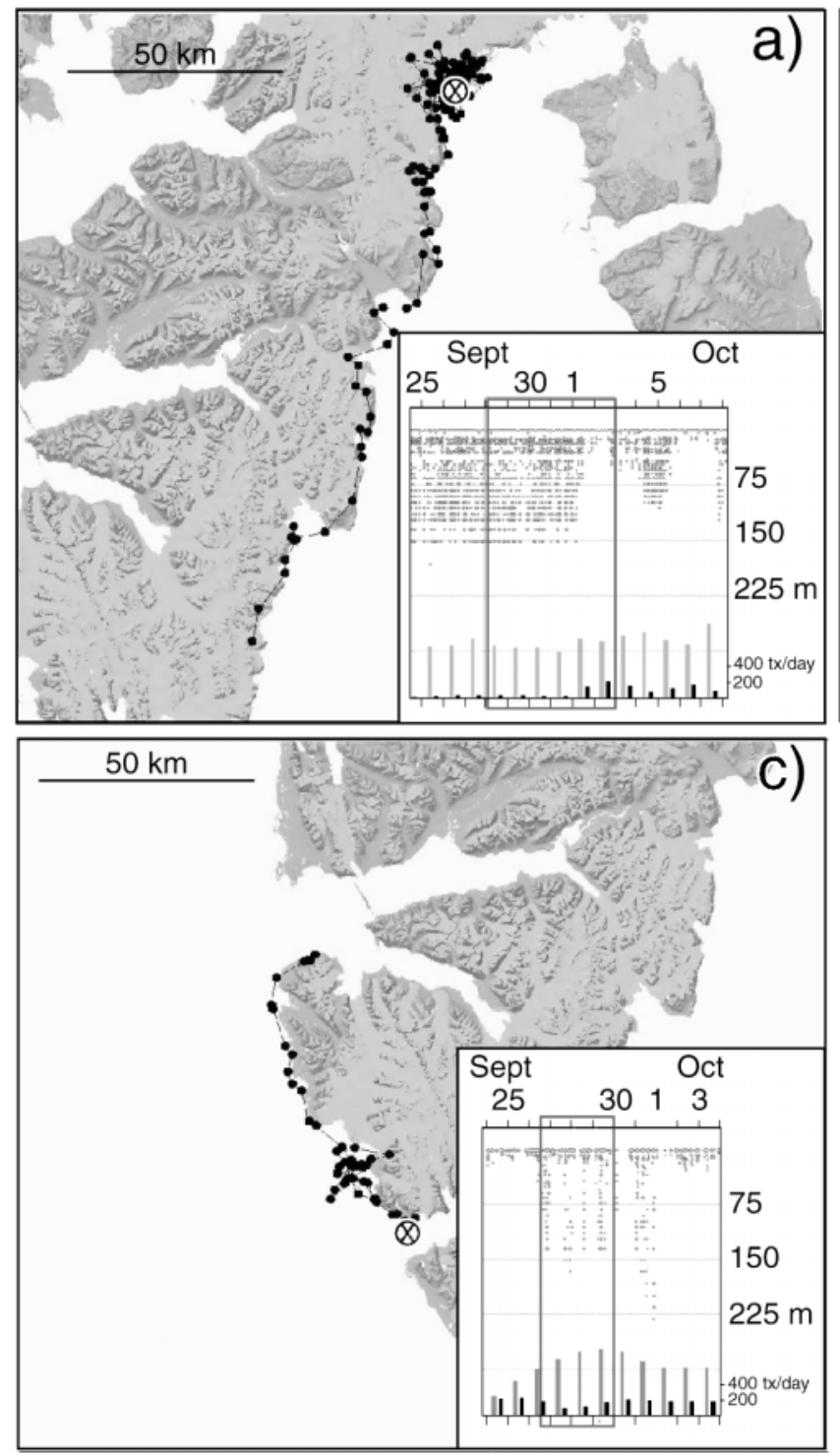

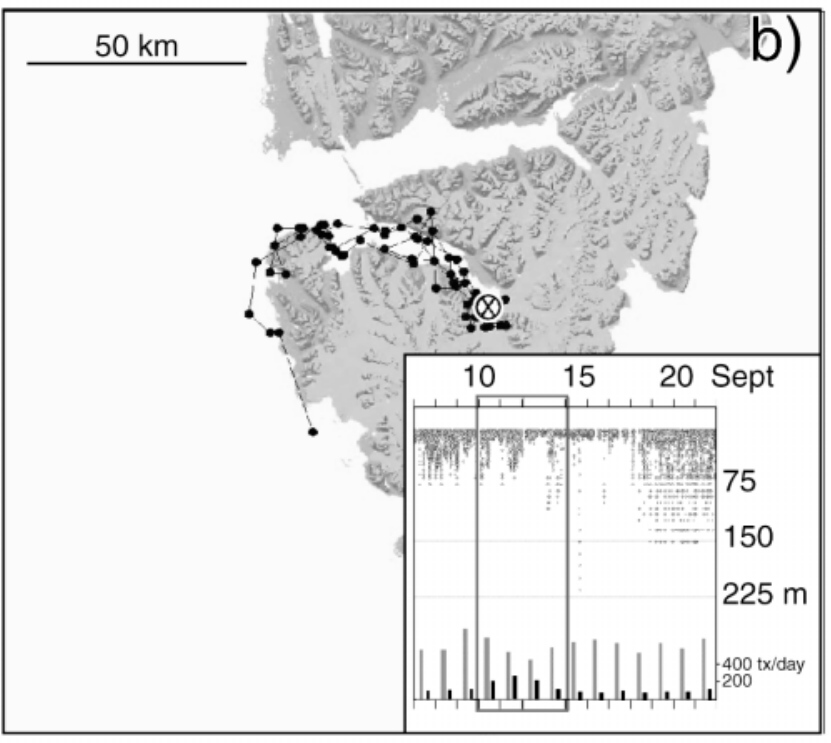

Fig. 2. Delphinapterus leucas. Maps with track-lines and corresponding strip-charts (inserts) from individual whales showing the basis for classification of movement data into different activity categories. Track-line in each map starts at Symbol $\otimes$. Rectangle inside each strip-chart frames the time during which the movements identified on the track-line in each of the respective maps took place; $y$-axis on the stripchart shows depth (upper part of axis) and number of transmissions per day (tx/day: lower part of axis). Light grey bars in the tx/day-plot represent successful transmissions, black bars aborted transmissions. (a) Track-line showing glacier front stationary activity followed by a coastal movement; during the glacier front stationary activity the whale stayed within a very restricted geographical area (at a glacier front); the strip-chart shows that the spot-depths indicate relatively deep diving and the number of aborted transmissions is low. Then on 1 September a coastal movement started, and during this activity spot-depths were shallow and a relative high number of aborted transmissions occurred. (b) In-fjord movement whereby the whale moved back and forth within a fjord; this activity pattern was accompanied by highly variable spotdepths and a relatively high number of aborted transmissions. (c) Coastal stationary activity, whereby the whale stayed for a period of time at a restricted location along the coast; accompanying strip-chart shows relatively deep spot-depths and a low number of aborted transmissions compared with the preceding and following coastal movement activities 


\section{RESULTS}

A total of 15 adult Delphinapterus leucas were equipped with SRDLs during this study. The first 7 individuals were all males, captured and released in the van Mijenfjorden/van Keulenfjorden area on the west coast of Spitsbergen (Table 1, Fig. 1). The remaining 8 whales, 7 males and 1 female, were captured and released in the northernmost part of Storfjorden on the east coast of Spitsbergen (Table 1, Fig. 1). A total of $844 \mathrm{~d}$ with tracking data were recorded from the 15 SRDLs, with an average longevity of $56 \pm 30$ (SD) d (range 7 to $120 \mathrm{~d}$ : Table 1). The tracking data show that the movements of the tagged whales were extremely coastal (Fig. 1). One exception is the track of a whale tagged in 1997 (Fig. 1d, lower right) whose tag failed to transmit for a long period, then suddenly started transmitting again and sent data for several weeks in November. The offshore locations for this whale corresponded to the southern ice edge in this area at that time.

It is difficult to get a realistic impression of the dynamics of the movements from the crude plots in Fig. 1. Track-lines for individual whales for each year often overlap, and in some cases whales moved together. The 3 individuals captured in 1997 were tagged together and moved together for at least as long as the tags transmitted positions (Fig. 1d). In 1999, all whales were tagged at the same location, and from Fig. 1f, it is evident that many of the track-lines overlap. However, these whales were not travelling together as a group. Fig. 3 illustrates some of the movement dynamics of these individuals. The 6 tagged whales were initially located in the capture area on 20 August (Fig. 3a).
Table 2. Activity budget for white whales in Svalbard

\begin{tabular}{|lcr|}
\hline Activity & Time (h) & $\%$ \\
\hline In-fjord movements & 1661 & 10.6 \\
Glacier front stationary & 8752 & 55.6 \\
Coastal movements & 4091 & 26.0 \\
Coastal stationary & 1226 & 7.8 \\
Total & 15730 & \\
\hline
\end{tabular}

Then, 2 individuals started to move southwards along the east coast of Spitsbergen on 24 August (Fig. 3b). A week later a third individual left the capture area, moving along the east coast of Storfjorden (Fig. 3c). By 3 September, 5 of the 6 whales had left the capture area (Fig. 3d). Four of these were grouped together inside Hornsund on 10 September (Fig. 3e). At this point in time, 1 tag failed. All functional tags were back in the capture area again by 3 October (Fig. 3i).

Activity budgets based on the movement patterns of the whales ( $655.4 \mathrm{~d}$ of analysed activity) show that they spent $55.6 \%$ of their time stationary in front of glaciers and $7.8 \%$ of their time stationary along the coast (Table 2). The proportion of time spent in coastal movements increased, and that spent in in-fjord movements decreased as the season progressed (Fig. 4).

The whales spent most of their time $(63.4 \%)$ relatively sedentary, either in front of glaciers or along the coast; when they changed locations, they did so in an apparently directed and rapid manner. If we analyse all the coastal movements for the whales over the last $3 \mathrm{yr}$ of the study $(\mathrm{n}=9)$ when the tracking data were best, then they spent a total of $3747 \mathrm{~h}$ in such activity. During this period they moved a total of $13176 \mathrm{~km}$,

Table 1. Delphinapterus leucas. Data on white whales from Svalbard that were equipped with satellite transmitters. Whale no. denotes yr of capture, i.e. DL95-1: 1st capture of 1995; DL-95-2: 2nd capture of 1995; etc.

\begin{tabular}{|c|c|c|c|c|c|c|}
\hline Whale no. & Capture date & Capture location & Tag ID & Sex & $\begin{array}{l}\text { Body length } \\
\text { (m) }\end{array}$ & $\begin{array}{c}\text { Tag longevity } \\
\text { (d) }\end{array}$ \\
\hline DL95-1 & Jul 7 & van Mijenfjorden: $77^{\circ} 45^{\prime} \mathrm{N}, 15^{\circ} 40^{\prime} \mathrm{E}$ & 8753 & M & 4.20 & 31 \\
\hline DL95-2 & Jul 7 & van Mijenfjorden: $77^{\circ} 49^{\prime} \mathrm{N}, 16^{\circ} 51^{\prime} \mathrm{E}$ & 17000 & M & 4.05 & 59 \\
\hline DL95-3 & Jul 9 & van Mijenfjorden: $77^{\circ} 51^{\prime} \mathrm{N}, 16^{\circ} 18^{\prime} \mathrm{E}$ & 17009 & M & 4.65 & 32 \\
\hline DL96-1 & Jul 20 & van Keulenfjorden: $77^{\circ} 27^{\prime}$ N, $16^{\circ} 06^{\prime} \mathrm{E}$ & 5805 & M & 4.35 & 7 \\
\hline DL97-1 & Aug 4 & van Mijenfjorden: $77^{\circ} 50^{\prime} \mathrm{N}, 15^{\circ} 57^{\prime} \mathrm{E}$ & 5800 & M & 4.60 & 120 \\
\hline DL97-2 & Aug 4 & van Mijenfjorden: $77^{\circ} 50^{\prime} \mathrm{N}, 15^{\circ} 57^{\prime} \mathrm{E}$ & 5803 & M & 4.25 & 81 \\
\hline DL97-3 & Aug 4 & van Mijenfjorden: $77^{\circ} 50^{\prime} \mathrm{N}, 15^{\circ} 57^{\prime} \mathrm{E}$ & 5801 & M & 4.30 & 52 \\
\hline DL98-1 & Aug 22 & Storfjorden: $78^{\circ} 36^{\prime} \mathrm{N}, 20^{\circ} 00^{\prime} \mathrm{E}$ & 8757 & $\mathrm{~F}$ & 3.75 & 63 \\
\hline DL98-2 & Aug 23 & Storfjorden: $78^{\circ} 31^{\prime} \mathrm{N}, 18^{\circ} 55^{\prime} \mathrm{E}$ & 5804 & M & 3.70 & 22 \\
\hline DL99-1 & Aug 18 & Storfjorden: $78^{\circ} 31^{\prime} \mathrm{N}, 18^{\circ} 55^{\prime} \mathrm{E}$ & 8754 & M & 4.25 & 56 \\
\hline DL99-2 & Aug 18 & Storfjorden: $78^{\circ} 31^{\prime} \mathrm{N}, 18^{\circ} 55^{\prime} \mathrm{E}$ & 5805 & M & 4.00 & 93 \\
\hline DL99-3 & Aug 18 & Storfjorden: $78^{\circ} 31^{\prime} \mathrm{N}, 18^{\circ} 55^{\prime} \mathrm{E}$ & 5803 & M & 4.05 & 63 \\
\hline DL99-4 & Aug 19 & Storfjorden: $78^{\circ} 31^{\prime} \mathrm{N}, 18^{\circ} 55^{\prime} \mathrm{E}$ & 8756 & M & 4.30 & 65 \\
\hline DL99-5 & Aug 20 & Storfjorden: $78^{\circ} 31^{\prime} \mathrm{N}, 18^{\circ} 55^{\prime} \mathrm{E}$ & 5801 & M & 4.65 & 74 \\
\hline DL99-6 & Aug 20 & Storfjorden: $78^{\circ} 31^{\prime} \mathrm{N}, 18^{\circ} 55^{\prime} \mathrm{E}$ & 5800 & M & 4.40 & 26 \\
\hline Total & & & & & & 844 \\
\hline
\end{tabular}


giving an average horizontal movement speed of $3.5 \mathrm{~km} \mathrm{~h}^{-1}$. If we consider the coastal movements of these 9 whales on an individual basis, their average horizontal movement speed was $3.7 \pm 0.5$ (SD) $\mathrm{km} \mathrm{h}^{-1}$ (range 3.0 to $4.3 \mathrm{~km} \mathrm{~h}^{-1}$ ). During short periods the whales moved much faster than this. For example, the
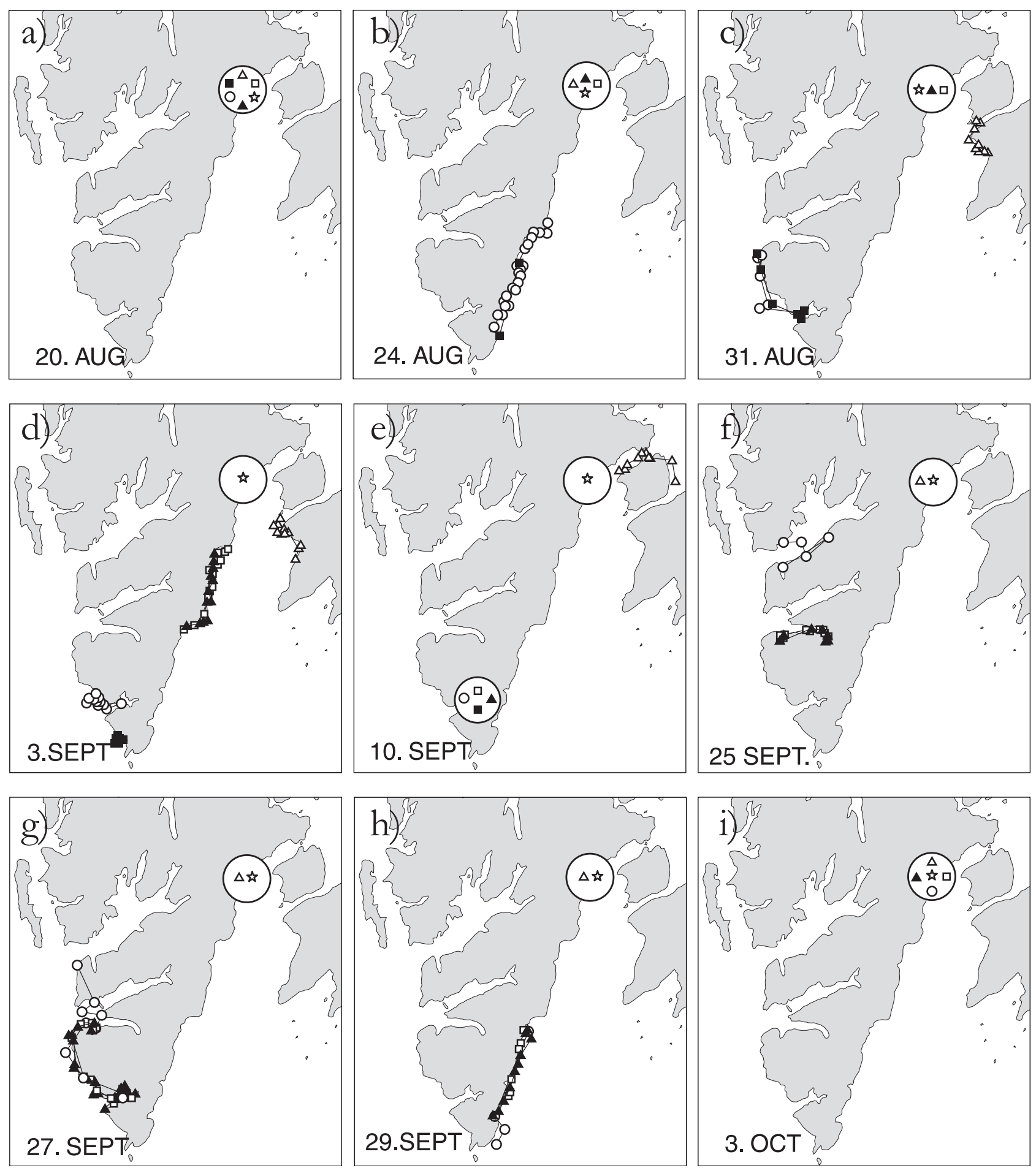

Fig. 3. Delphinapterus leucas. Movements of 6 white whales (symbols represent individual whales) in Svalbard during the period 20 August to 3 October 1999. Each individual track is $24 \mathrm{~h}$ in duration; when a whale was stationary during this $24 \mathrm{~h}$ period, its symbol is circled. For further details see text 'Results' 
3 whales from 1997, which left the mouth of van Keulenfjorden on the west coast of Spitsbergen on 14 August, rounded Sørkapp and followed the coastline north to the inner parts of Storfjorden in $72 \mathrm{~h}$. This distance is about $430 \mathrm{~km}$ in a straight line, so their horizontal swimming speed must have been at least $6 \mathrm{~km} \mathrm{~h}^{-1}$.

\section{DISCUSSION}

This study documented that Delphinapterus leucas in Svalbard spend most of their time $(55.6 \%)$ in front of glaciers during summer and autumn. The large glacier front in the north of Storfjorden is the location where they are most frequently located, but the glaciers in all bays and fjords on both the east and west coasts of Spitsbergen are also visited regularly. There could be several explanations why glacier fronts are such attractive sites for white whales in this area. In other regions of the Arctic, white whales enter rivers and estuaries during certain periods of the year. They are thought to do so in part because river water may provide a thermoregulatory advantage for young-ofthe-year, which have a relatively thin blubber layer. It has also been suggested that these movements into fresh, warmer water may enhance moulting activities (St Aubin et al. 1990, Boily 1995). Rivers in the Svalbard area are too shallow to enable white whales to enter them. But, there are large outflows of freshwater in this area, found in association with glacier fronts. Huge quantities of freshwater are discharged into the ocean either as sub-surface or surface rivers produced largely via the melting of the glacier. So the area in front of glaciers in Svalbard, at least in terms of freshwater supply, could be comparable to river systems in other areas of the Arctic for the whales. However, the temperature of this water during the period when the white whales were tracked in Svalbard would be colder than the underlying and surrounding salt water, so there would be no thermoregulatory advantage to occupying these areas. In addition, all adults that were tagged (except No. DL96-1) had moulted. Thus, none of the common explanations for why white whales search out freshwater areas seem to apply.

Another, more likely, reason for the observed movement patterns of white whales in Svalbard is that areas in front of glaciers in the fjords of Svalbard probably contain significant quantities of prey for the whales. Upwellings occur at the face of glaciers because the freshwater moving out of the glacier induces subsurface water to rise to replace it (Dunbar 1951). This brings nutrients up to the surface, which fertilise a phytoplankton and ultimately a zooplankton bloom (Dunbar 1968, Appolonio 1973, Jacobs et al. 1979,

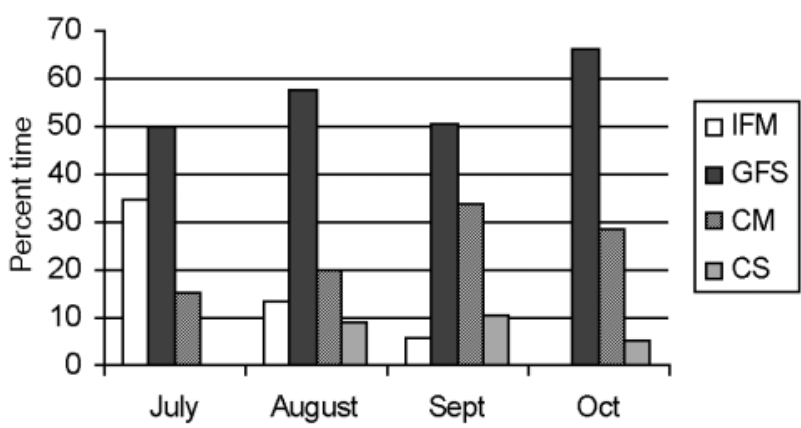

Fig. 4. Delphinapterus leucas. Seasonal variation in different activities for white whales in Svalbard based on $655 \mathrm{~d}$ of records. IFM: in fjord movements; GFS: glacier front stationary; CM: coastal movements; CS: coastal stationary

Weslawki et al. 2000). The freshwater also serves to stun or kill invertebrates, providing an added attraction to avian, fish and in turn, mammalian predators. This phenomenon of marine predators being attracted to areas of upwelling caused by glaciers, bathymetric features or ocean-front areas is very well documented for sea birds and has been suggested for both whales and seals (e.g. Benjaminsen \& Christensen 1980, Brown 1980, Mehlum 1984). Fishes in the Svalbard area that could be attracted to high-productivity areas such as glacial fronts include schooling fishes such as polar cod Boreogadus saida and capelin Mallotus villosus. These species are known to be favoured prey of white whales in other regions (Seaman et al. 1982, Boltunov \& Belikov 1999), and fatty acid analyses of the blubber of white whales from Svalbard suggests that these species are major components of the diet of white whales in Svalbard (Dahl et al. 2000). Coastal stationary activity probably represents feeding as well, based on the consistency of depth profiles recorded during this behavioural activity. However, the type of prey that might occur at those locations at which this behaviour is performed, and why it should be concentrated at some specific sites along the coast, are factors requiring investigation.

Coastal movement activity, due to its extremely shallow, coastal and directed nature, probably simply reflects transport between areas of interest for other activities. In-fjord movement activity appears to represent a mixture of transport between areas and feeding. Polar cod are commonly, albeit erratically, found in the fjords of Svalbard during the ice-free periods of the year (Falk-Petersen et al. 1986).

There is a seasonal change in the different activities (Fig. 4). Those that are thought to represent feeding (glacier front stationary and coastal stationary) increase from $50 \%$ of the time in July to about $72 \%$ in October. This shift in activity may reflect whales recov- 
ering their energy reserves after the spring/summer breeding activities.

A question that arises is why do the white whales leave Storfjorden at all if this place has such an abundance of food? Why waste energy moving to another food patch in front of another glacier hundreds of kilometres away? It is unlikely that the whales manage to exhaust their food source in Storfjorden even temporarily, since some individuals do stay there all the time, and those that move out return again. Studies of optimal foraging indicate that this type of prey-patch shifting behaviour may represent a long-term adaptation to a fluctuating environment (Pyke et al. 1977). In areas where animals can depend on specific locations for feeding, it would be reasonable to expect them to allocate all their time to the area with the highest abundance of food (Pyke et al. 1977). However, in a fluctuating environment, a good long-term strategy may be to visit different feeding areas with some regularity and yet spend the largest fraction of time in the area that has the highest food abundance, and progressively less time in areas with progressively less food. Animals can then monitor changes in food abundance between areas, and adjust their time according to temporal changes in food in each respective area (Pyke et al. 1977). The northern parts of Storfjorden are obviously very important as a foraging area for the white whales in Svalbard during summer and autumn. However, food is also found in other areas. By checking these other areas with some regularity, the whales might be employing a bet-hedging strategy that allows them to adjust readily to changes in the environment at some of their feeding locations.

One striking feature in this study is the extremely coastal nature of the movement patterns of these white whales (see Fig. 1). In other places in the Arctic (Richard et al. 1997), white whales move long distances offshore, but the whales in the present study rarely moved even a few kilometres offshore. One reason for the observed movement pattern could simply be that following the shoreline is the shortest distance between preferred habitat areas, namely glacier fronts. However, it is known from behavioural studies of white whales that when they are frightened, they tend to move either into the ice or closer to shore (Finley et al. 1990). This special behaviour, which also usually involves rapid swimming, herd formation and asynchronous shallow dives is referred to as 'ardlingayuk' by Inuits, which means fear of killer whales (Orcinus orca) (Finley et al. 1990). Killer whales do prey on white whales (Kleinenberg et al. 1969, George \& Suydam 1998); they were often observed in the Svalbard area during the summer months, and were previously hunted in the study area (Øien 1988). Other potential sources of alarm, such as noise from boats, should not represent a big problem for white whales in the Svalbard area. In fact, the only place where any significant engine noise is produced is the harbour area in Adventfjorden in the vicinity of the town Longyearbyen, and this area is regularly visited by white whales during the busy (noisy) summer months. Thus, the most likely explanation for the observed movement patterns of white whales in Svalbard is anti-predator behaviour. Another fact that supports this interpretation of the coastal movement patterns is that Svalbard white whales are unusually quiet (few vocalisations) compared to white whales from other areas, at least during the summer months (Karlsen et al. 1999).

The horizontal swimming speeds calculated in this study are obviously minimum speeds. The distances that formed the basis for these calculations were measured as straight lines between transmitted positions. The whales undoubtedly deviated from linear position changes. In addition, the whales dive, and no movements in this third dimension are accounted for by 2-dimensional measurements along the surface. Straight-line speeds for whales in Canadian waters, measured in a fashion similar to ours, commonly recorded speeds between 2 and $4 \mathrm{~km} \mathrm{~h}^{-1}$, with the fastest sustained speed record being $5.8 \mathrm{~km} \mathrm{~h}^{-1}$ (Martin et al. 1993). These speeds are very similar to those recorded in this study. The swimming and diving performance of trained adult white whales suggest that their optimum swimming speed (i. e. without increasing oxygen consumption) is $2 \mathrm{~m} \mathrm{~s}^{-1}\left(7.2 \mathrm{~km} \mathrm{~h}^{-1}\right.$ : Shaffer et al. 1997).

All captures in 1999 were in the north of Storfjorden. All these whales stayed in the capture area for a short period (Fig. 3), and then moved over large areas. Some appeared to meet at irregular intervals before they all arrived in the north of Storfjorden 5 to 6 wk later (Fig. 3). We have observed tagged whales on several occasions, including those in 1999, and they have always been part of a larger group. Thus, the dynamics of the movements illustrated in Fig. 3 probably represent movement patterns of groups rather than individuals. Belkovitch \& Shekotov (1993) described 'pods' of white whales as discrete social units. However, these authors suggested that due to variation in factors such as prey size, prey density, water depths and breeding status, the pod may fragment for short periods of time (Belkovitch \& Shekotov 1993). Thus, the white whales in Storfjorden may be parts of the same pod that splits up into smaller units for shorter periods for various reasons. Another plausible explanation could be that Storfjorden is a summer area for many different groups of white whales.

The average longevity of the tags in this study was $56 \mathrm{~d}$, which is somewhat longer than the average in 
other studies (30.2 to 42 d) (Martin et al. 1993, Richard et al. 1997, 1998). This may simply be coincidental, but there are several other possible explanations. All the whales in this study were adults, and 14 of the 15 were adult males. Adult individuals have thicker skin than sub-adults, and adult males are generally larger and have thicker skin than adult females. Thus, by using more adult males, the rejection rate of the tags may be slower than when tags are deployed on other sex- and age-groups. Another factor may be moulting. In the present study, 14 of 15 of the whales had pure white skin, indicating that the annual moult had occurred recently (St Aubin et al. 1990). The exception was Whale DL96-1 (Table 1), the whale with the shortest tag retention time in this study. This whale had nicotine-yellow-coloured patches on its dorsal surface, and thus had not yet been though its annual moult. White whales are known to rub themselves on gravel on the sea bottom to speed up the moulting process (Finley 1982), and this behaviour may have resulted in the satellite tag being ripped off this whale. A third factor that might have increased the longevity of the tags in this study is improved tag design and attachment methodology. The size of the tags is much smaller and they were much more streamlined than tags deployed 10 yr ago.

This study has documented that the white whales in Svalbard spend most of their time during summer in areas fronting the many glaciers in the archipelago, probably because of the high abundance of food in these areas. When the whales change location, they do so in an apparently directed and quick manner. The whales move very close to shore, which may be an adaptation to avoid killer whale predation. White whales in Svalbard do not appear to undergo a systematic migration like many populations of this species do, and may represent an isolated stock. The small spatial scale involved in the movements of the white whales in Svalbard provides a remarkable opportunity to explore the ecology of foraging behaviour and habitat choice of this species in detail. For example, sites where coastal clusters occur with some regularity as well as glacier fronts should be explored with respect to their productivity. Additionally, studies should be initiated to establish where these whales move when the ice forms in the fjords in the winter and whether they are genetically linked to individuals in the Greenland Sea or the Russian Barents or White Seas.

Acknowledgements. We thank Gro Andersen, Kristin Bang, Trine Dahl, Outi Dove, Hans Lund and Erling Nordøy for their help in the field. We also thank Mike Fedak, Phil Lovell and Bernie McConnell for directing us through the MAMVIS computer visualisation programme. This study was supported by funds from the Norwegian Polar Institute, the University Courses in Svalbard (UNIS), and the Sea Mammal Research Unit (SMRU).

\section{LITERATURE CITED}

Appolonio S (1973) Glaciers and nutrients in arctic seas. Science 180:491-493

ARGOS (1989) Guide to the Argos system. Argos CES, Toulouse

Belkovitch VM, Shekotov MN (1993) The belukha whale: natural behaviour and bioacoustics. Woods Hole Oceanographic Institution, Woods Hole, MA

Benjaminsen T, Christensen I (1980) The natural history of the bottlenose whale, Hyperoodon ampullatus Forster. In: Winn HE, Olla BL (eds) Behaviour of marine animals. Cetaceans 3:143-164

Boily P (1995) Theoretical heat flux in water and habitat selection of phocid seals and beluga whales during annual moult. J Theor Biol 172:235-244

Boltunov AN, Belikov SE (1999) Beluga (Delphinapterus leucas) of the Barents, Kara and Laptev Seas. NAMMCO Scientific Committee Meeting, Oslo, March 1999 SC/7/BN/7

Brodie PF (1971) A reconsideration of aspects of growth, reproduction, and behavior of white whale (Delphinapterus leucas), with reference to the Cumberland Sound, Baffin Island, population. J Fish Res Board Can 28: 1309-1318

Brown GB (1980) Seabirds as marine animals. In: Burger J, Olla BL, Winn E (eds) Behaviour of marine animals, marine birds, Vol. 4. Plenum Press, NY, p 1-39

Dahl TM, Lydersen C, Kovacs KM, Falk-Petersen S, Sargent J, Gjertz I, Gulliksen B (2000) Fatty acid composition of the blubber in white whales (Delphinapterus leucas). Polar Biol 23:401-409

Dunbar MJ (1951) Eastern arctic waters. Bull Fish Res Board Can 8:1-131

Dunbar MJ (1968) Ecological development in polar regions. Prentice-Hall, Inc, Englewood Cliffs, NJ

Falk-Petersen IB, Frivoll V, Gulliksen B, Haug T (1986) Occurrence and size/age relations of polar cod (Boreogadus saida) (Lepechin), in Spitsbergen coastal waters. Sarsia 71: 235-245

Fedak MA, Lovell P, McConnell BJ (1996) MAMVIS, a marine mammal behaviour visualisation system. J Visual Comput Anim 7:141-147

Finley KJ (1982) The estuarine habit of the beluga or white whale Delphinapterus leucas. Cetus J Moclips Cetolog Soc $4: 4-5$

Finley KJ, Miller GW, Davis RA, Green CR (1990) Reactions of belugas, Delphinapterus leucas, and narwhals, Monodon monoceros, to ice-breaking ships in the Canadian high Arctic. In: Smith TG, St Aubin DJ, Geraci JR (eds) Advances in research on the beluga whale, Delphinapterus leucas. Can Bull Fish Aquat Sci 224:97-117

George JC, Suydam R (1998) Observations of killer whale (Orcinus orca) predation in the northeastern Chukchi and western Beaufort Seas. Mar Mamm Sci 14:330-332

Gjertz I, Wiig 0 (1994) Distribution and catch of white whales (Delphinapterus leucas) at Svalbard. Medd Grønland (Biosci) 39:93-97

Jacobs SS, Gordon AL, Amos AF (1979) Effects of glacial ice melting on Antarctic surface water. Nature 277:469-471

Karlsen J, Bisther A, Lydersen C, Kovacs KM, Haug T, Gjertz I (1999) Vocalizations of white whales (Delphinapterus leucas) summering around Svalbard, Norway. Thirteenth Biennial Conference on the Biology of Marine Mammals. Wailea, Maui, Hawaii, Nov 28-Dec 3, 1999, p 94

Kleinenberg SE, Yablokov AV, Belkovich BM, Tarasevich MN (1969) Beluga (Delphinapterus leucas). Investigation of the species. IPST Press, Jerusalem 
Lønø O, Øynes P (1961) White whale fishery at Spitsbergen. Norsk Hvalfangsttid 50:267-287

Martin AR, Smith TG, Cox OP (1993) Studying the behaviour and movements of high Arctic belugas with satellite telemetry. Symp Zool Soc Lond 66:195-210

McConnell BJ, Chambers C, Fedak MA (1992) Foraging ecology of southern elephant seals in relation to bathymetry and productivity of the Southern Ocean. Antarct Sci 4:393-398

Mehlum F (1984) Concentrations of seabirds along the face of glaciers and outlets of rivers in Svalbard. Fauna (Oslo) 37 : 156-160 (In Norwegian with English summary)

Øien N (1988) The distribution of killer whales (Orcinus orca) in the North Atlantic based on Norwegian catches, 1938-1981, and incidental sightings, 1967-1987. Rit Fiskid 11:65-78

Pyke GH, Pulliam H, Charnov EL (1977) Optimal foraging: a selective review of theory and tests. Q Rev Biol 52:137-154

Richard PR, Martin A, Orr JR (1997) Study of summer and fall movements and dive behavior of Beaufort Sea belugas, using satellite telemetry: 1992-1995. Environmental Studies Research Funds No. 134, Calgary

Richard PR, Heide-Jörgensen MP, St Aubin DJ (1998) Fall movements of belugas (Delphinapterus leucas) with satellite-linked transmitters in Lancaster Sound, Jones Sound,

Editorial responsibility: Otto Kinne (Editor),

Oldendorf/Luhe, Germany and northern Baffin Bay. Arctic 51:5-16

Richard PR, Martin A, Orr JR (2001) Summer and autumn movements of belugas of the eastern Beaufort Sea stock. Arctic (in press)

Seaman GA, Lowry LF, Frost KJ (1982) Foods of belukha whales (Delphinapterus leucas) in western Alaska. Cetology 44:1-19

Shaffer SA, Costa DP, Williams TM, Ridgway SH (1997) Diving and swimming performance of white whales, Delphinapterus leucas: an assessment of plasma lactate and blood gas levels and respiratory rates. J Exp Biol 200: 3091-3099

Smith TG, Martin AR (1994) Distribution of belugas, Delphinapterus leucas, in the Canadian high Arctic. Can J Fish Aquat Sci 51:1653-1663

Smith TG, St Aubin DJ, Hammill MO (1992) Rubbing behaviour of belugas, Delphinapterus leucas, in a high Arctic estuary. Can J Zool 70:2405-2409

St Aubin DJ, Smith TG, Geraci JR (1990) Seasonal epidermal moult in beluga whales, Delphinapterus leucas. Can J Zool 68:359-367

Weslawski JM, Pedersen G, Petersen SF, Porazinski K (2000) Entrapment of macroplankton in an Arctic fjord basin, Kongsfjorden, Svalbard. Oceanologia 42:57-69

Submitted: October 9, 2000; Accepted: January 15, 2001 Proofs received from author(s): August 2, 2001 